\title{
Effects of press parameters on some technological properties of
}

\section{polystyrene composite plywood}

\author{
Cenk DEMIRKIR ${ }^{1}$, Hasan ÖZTÜRK ${ }^{2 *}$, Gürsel ÇOLAKOĞLU ${ }^{1}$ \\ ${ }^{1}$ Karadeniz Technical University, Faculty of Forestry, Department of Forest Industry Engineering, \\ Trabzon, TURKEY \\ ${ }^{2}$ Karadeniz Technical University, Arsin Vocational School, Department of Materials and Material \\ Processing Technologies, Trabzon, TURKEY \\ *Corresponding Author: hasanozturk@ktu.edu.tr
}

Received Date: 12.01.2017

Accepted Date: 13.11.2017

\section{Abstract}

Aim of study: Formaldehyde content of most of resins used in wood based composite production, wood composite materials have been seen a threat on human health and environment. Therefore, numerous studies have been made to develop an effective method to decrease formaldehyde emission from the wood based panels and various methods have been tried. The aim of the study was to investigate those effects of press parameters on some technological properties of polystren composite plywood.

Area of study: This study was conducted at the Pilot Facility of Department of Forest Industry Engineering, Karadeniz Technical University in Trabzon, Turkey.

Material and Methods: Poplar (Populus deltoides) veneers were used to produce polystren composite plywood. Urea-formaldehyde adhesive was used as bonding material for traditional plywood panels. Three different press temperature $\left(130,140,150{ }^{\circ} \mathrm{C}\right)$ and pressing time $(6,8,10$ minutes) were chosen as press parameters in the manufacturing of polystren composite plywood. Bonding strength, bending strength, modulus of elasticity, density and equilibrium moisture content of panels were determined according to TS EN 314-1, TS EN 310, TS EN 323 and TS EN 322, respectively.

Main results: The experimental results showed that mechanical properties and density of panels generally increased with increasing press temperature and pressing time whereas the equilibrium moisture content of panels decreased.

Research highlights: This study showed that polystyrene wastes can be used in plywood manufacturing as an alternative bonding material for interior uses.

Keywords: Polystren composite plywood, Press parameters, Press temperature, Pressing time

\section{Polistren kompozit kontrplakların bazı teknolojik özellikleri üzerine pres parametrelerinin etkileri}

\section{Özet}

Çalışmanın amacı: Ahşap kompozit malzemelerin üretiminde kullanılan tutkalların birçoğu formaldehit içeriği nedeniyle insan ve çevre sağlığı açısından bir tehdit unsuru olarak görülmektedir. Bu nedenle odun kökenli levhalarda ki formaldehit emisyonunun azaltılmasına yönelik etkili metotların geliştirilmesi için birçok çalışma yapılmış ve çeşitli yöntemler denenmiştir. Bu çalışmada polistren kompozit kontrplakların bazı teknolojik özellikleri üzerine pres parametrelerinin etkilerinin araștırılması amaçlanmıştır.

Çalışma alanı: Bu çalışma, Trabzon'daki Karadeniz Teknik Üniversitesi Orman Endüstri Mühendisliği Bölümü Pilot tesisinde yapılmıştır.

Materyal ve Yöntem: Polistren kompozit kontrplakların üretiminde kavak (Populus deltoides) kaplamalar kullanılmıştır. Geleneksel kontrplakların üretiminde yapıştırıcı olarak ÜF tutkalı kullanılmıştır. Polistren kompozit kontrplakların üretiminde farklı pres sıcaklıkları $\left(130,140,150^{\circ} \mathrm{C}\right)$ ve pres süreleri $(6,8,10$ dakika) seçilmiştir. Levhaların, çekme makaslama direnci TS EN 314-1, eğilme direnci ve elastikiyet modülü TS EN 310, özgül ağırlıkları TS EN 323 ve denge rutubet miktarları TS EN 322 standartlarına göre belirlenmiştir.

Sonuçlar: Yapılan deneyler sonucunda genel olarak levhaların mekanik özelliklerinin ve yoğunluk değerlerinin pres sıcaklığı ve pres süresinin artmasına bağlı olarak artış gösterdiği görülürken denge rutubet miktarlarının azaldığı görülmüştür.

Araştırma vurguları: Bu çalışma, polistiren atıklarının kontrplak üretiminde iç mekan kullanımları için alternatif bir yapıştırma malzemesi olarak kullanılabileceğini ortaya koymuştur.

Anahtar Kelimeler: Polistren kompozit kontrplak, Pres parametreleri, Pres sıcaklığı, Pres süresi 


\section{Introduction}

Wood-based composites are one of the largest manufactures worldwide and are widely used in diverse fields, including windows and door frames, floors and interior panels in cars contributing to their popularity (Fang, Chang, Guo, Ren \& Wang, 2013, p. 740). Plywood which is one of the most important wood based composite panels has many usage areas (Demirkir, Ozsahin, Aydin \& Colakoglu, 2013, p. 15). Compared with solid wood, the chief advantages of plywood are that the properties along the length of the panel are more nearly equal to properties along the width, there is greater resistance to splitting, and the form permits many applications where large sheets are desirable (Aydin \& Colakoglu, 2008, p. 371). Formaldehyde-based adhesives such as urea(UF), phenol-and melamine-formaldehyde resins are used widely in the ply-wood manufacturing industry (Luo, Luo, Gao \& Li, 2015 , p. 281). Additionally, formaldehyde is a potential human carcinogen and, because of its high danger level, is classified differently than most other pollutants (Bohm, Salem \& Srba, 2012, p. 221). Also, The International Agency for Research on Cancer (IARC) in 1995 attached to formaldehyde in terms of human health "Possible Carcinogenic Substances" class and the ratio of formaldehyde can release from wood based materials was limited in most of country (IARC, 2004; Colakoglu, 1993, p. 21). After this area investigated comprehensively, IARC in June 2004 remove formaldehyde from "Possible Carcinogenic Substances" class and identified as an agent caused directly carcinogen for human (Jianying, Tao, Yingyan, Min \& Xia, 2010, p. 1). As a result, there is an urgent need for the development of formaldehyde-free wood adhesives. Significant efforts have been made to reduce or replace formaldehyde contents in adhesive formulations. Although some of these new adhesives have already been used in industrial applications, their supply is limited which may be due to the high modification costs or some weak properties, for example, low waterresistance. (Fang, Chang, Guo, Ren \& Wang, 2013, p. 740).
Styrofoam, also known as expanded polystyrene, is widely used all over the world for various purposes including thermal insulation, packing, coffee cups, plates, food trays, fabrication of car parts etc. Styrofoam has many benefits including insulating quality, high durability and strength. On the other hand, due to the presence of benzene in styrofoam and hardly biodegradable nature, used polystyrene foam can become a big environmental problem unless it is recycled. Recently, the products manufactured from the recycled materials are especially paid attention in the viewpoint of environmental problems. The progress of such a recycling technology of products means that material recycling makes the technology economically and environmentally attractive. Especially, disposal of expanded polystyrene as a large amount of material abandoned in the advanced countries has a major concern. Wood- polystren composite (WPC) panels may be a very suitable solution for environmental pollution caused by styrofoam waste and also formaldehyde released from wood based panels such as plywood. WPC is manufactured from combining wood veneer sheets and polystyrene elements (styrofoam). WPC can be manufactured without synthetic resins such as urea-formaldehyde or phenolformaldehyde. Therefore WPC manufacturing can be suitable for both environmental and economic perspective. WPC manufacturing process also does not need a gluing machine or the preparation of glue mixture. So, the production process has been simplified (Demirkir, Colak \& Aydin, 2013, p. 514; Hu, Nakao, Nakai, Gu \& Wang, 2005, p. 13).

The aim of the study was to investigate of the some technological properties of plywood panels manufactured with polystren wastes in plywood production as a bonding material and optimal press conditions were determined for the WPC panels.

\section{Material and Methods}

Rotary cut veneer sheets with $50 \mathrm{~cm}$ by $50 \mathrm{~cm}$ dimensions and $2 \mathrm{~mm}$ thickness were obtained from freshly cut poplar (Populus deltoides) logs. The horizontal opening between knife and nosebar was $85 \%$ of the veneer thickness, and the vertical opening 
was $0.5 \mathrm{~mm}$ in rotary cutting process. The veneers obtained were dried to 5-7 \% moisture content by using a veneer dryer.

The urea-formaldehyde (UF) adhesive (with 55\% solid content) was used as a bonding material for traditional plywood panels. The mixture of adhesive was composed of 100 parts UF resin, 30 parts wheat flour and 10 parts $\mathrm{NH}_{4} \mathrm{Cl}$ with $15 \%$ concentration, by weight. Approximately 160 $\mathrm{g}$ adhesive mixture per square meter was spread on single surfaces of veneers by a four-roller gluing machine. 3-layer plywood panels were manufactured with adjacent layers having their wood grain at right angles to each other. Press temperature and duration were applied as $110{ }^{\circ} \mathrm{C}$ and 6 minutes, respectively.

After drying, it was formed woodpolystren composite (WPC) panel drafts. Wood-polystren composite panels manufactured with 3 layer as shown in Figure 1. The thickness of polystren type used in this study was $10 \mathrm{~mm}$. The density of polystren having $20 \mathrm{~kg} / \mathrm{m}^{3}$ was used for WPC panel production.

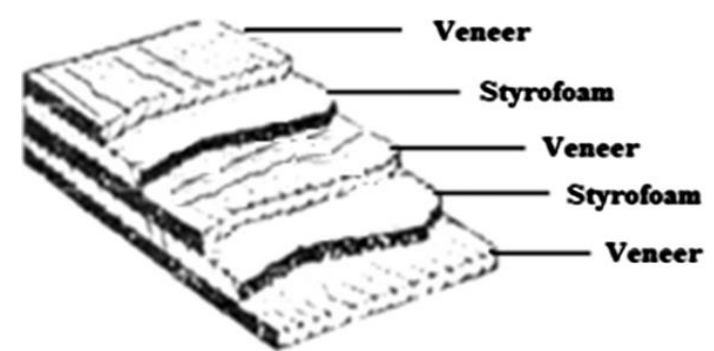

Figure 1. Structural design for three-layer wood-polystren composite panels
Three different hot press temperature $\left(130,140\right.$ and $\left.150^{\circ} \mathrm{C}\right)$ and pressing time $(6,8$ and 10 minutes) were applied as press parameters in the manufacturing of polystren composite plywood panels. In the manufacturing of both traditional plywood and WPC panels, hot press pressure were applied as $8 \mathrm{~kg} / \mathrm{cm}^{2}$.

Two replicate panels were manufactured for each test groups. Test panels were conditioned to reach equilibrium moisture content at $20{ }^{\circ} \mathrm{C}$ temperature and $65 \%$ relative humidity prior to testing.

The bonding strength of panels was determined according to TS EN 314-1 (1998) with a universal testing machine. Bending strength and modulus of elasticity values of panels were evaluated according to TS EN 310 (1999) standard. Density and equilibrium moisture content of the panels were determined according to TS EN 323-1 and TS EN 322 (1999) standards, respectively.

\section{Results and Discussion}

Average values for bonding strength, bending strength and modulus of elasticity of WPC and plywood panels are given in Table 1. Physical properties test results of WPC and plywood panels according to press temperature and pressing time were presented in Table 2.

Table 1. Bonding strength, bending strength and modulus of elasticity of panel groups

\begin{tabular}{|c|c|c|c|c|c|c|c|}
\hline \multirow{2}{*}{$\begin{array}{c}\text { Press } \\
\text { Temperature } \\
\left({ }^{\circ} \mathrm{C}\right)\end{array}$} & \multirow{2}{*}{$\begin{array}{l}\text { Pressing } \\
\text { Time } \\
\text { (min.) }\end{array}$} & \multicolumn{2}{|c|}{$\begin{array}{l}\text { Bonding } \\
\text { Strength } \\
\left(\mathrm{N} / \mathrm{mm}^{2}\right)\end{array}$} & \multicolumn{2}{|c|}{$\begin{array}{l}\text { Bending } \\
\text { Strength } \\
\left(\mathrm{N} / \mathrm{mm}^{2}\right)\end{array}$} & \multicolumn{2}{|c|}{$\begin{array}{l}\text { Modulus of } \\
\text { Elasticity } \\
\left(\mathrm{N} / \mathrm{mm}^{2}\right)\end{array}$} \\
\hline & & $X$ & $\mathrm{~S}$ & $X$ & $\mathrm{~S}$ & $X$ & $\mathrm{~S}$ \\
\hline 110 & 6 & 1.30 & 0.20 & 89.96 & 7.10 & 6950 & 340 \\
\hline \multirow{3}{*}{130} & 6 & 0.63 & 0.17 & 36.05 & 9.84 & 3414 & 479 \\
\hline & 8 & 1.09 & 0.22 & 54.32 & 8.79 & 4171 & 442 \\
\hline & 10 & 1.21 & 0.12 & 75.12 & 8.39 & 4658 & 288 \\
\hline \multirow{3}{*}{140} & 6 & 0.69 & 0.07 & 64.69 & 11.80 & 5965 & 739 \\
\hline & 8 & 1.12 & 0.14 & 73.74 & 8.85 & 6177 & 434 \\
\hline & 10 & 1.25 & 0.20 & 79.66 & 8.49 & 5253 & 914 \\
\hline \multirow{3}{*}{150} & 6 & 1.01 & 0.16 & 74.13 & 8.12 & 6717 & 529 \\
\hline & 8 & 1.18 & 0.17 & 74.54 & 10.40 & 6450 & 382 \\
\hline & 10 & 1.19 & 0.10 & 87.14 & 6.63 & 6725 & 370 \\
\hline
\end{tabular}

X: Arithmetic mean S: Standard deviation 
Table 2. Physical properties of panel groups

\begin{tabular}{cccccc}
\hline $\begin{array}{c}\text { Press } \\
\text { Temperature } \\
\left({ }^{\circ} \mathrm{C}\right)\end{array}$ & $\begin{array}{c}\text { Pressing } \\
\text { Time } \\
(\mathrm{min} .)\end{array}$ & \multicolumn{2}{c}{$\begin{array}{c}\text { Density } \\
\left(\mathrm{g} / \mathrm{cm}^{3}\right)\end{array}$} & \multicolumn{2}{c}{$\begin{array}{c}\text { Equilibrium } \\
\text { Moisture Content } \\
(\%)\end{array}$} \\
\cline { 3 - 6 } & 6 & 0.50 & 0.02 & 7.86 & 0.65 \\
\hline 110 & 6 & 0.47 & 0.04 & 5.72 & 0.21 \\
130 & 8 & 0.50 & 0.02 & 5.46 & 0.19 \\
& 10 & 0.54 & 0.03 & 5.50 & 0.22 \\
\hline \multirow{2}{*}{140} & 6 & 0.54 & 0.02 & 5.31 & 0.23 \\
& 8 & 0.55 & 0.02 & 5.15 & 0.18 \\
& 10 & 0.59 & 0.03 & 5.03 & 0.21 \\
\hline \multirow{2}{*}{150} & 6 & 0.55 & 0.02 & 4.87 & 0.25 \\
& 8 & 0.57 & 0.02 & 4.90 & 0.30 \\
\hline X: Arithmetic mean S: Standard deviation & 0.57 & 0.02 & 4.77 & 0.25 \\
\hline
\end{tabular}

As can be seen from Table 1, the results of all mechanical properties of traditional plywood panels manufactured with urea formaldehyde adhesive were found to be higher than those of WPC panels. The properties of plywood are dependent on the quality of the veneer sheets, the order of layers, the adhesive types, and the degree to which bonding conditions are controlled during production. Bonding strength occurred between wood elements affects all mechanical properties of the wood based panel products. For maximum adhesive bond strength, the liquid adhesive must wet the wood surface and penetrate into the wood. Adhesive molecules must contact directly with wood molecules to provide the best mechanical interlocking and intermolecular attraction. At the present study, UF adhesive has better wetting properties among all binding systems used. Therefore, the layers of UF bonded plywood panels may be better bonded to each other in the same production conditions. (Demirkir, Colak \& Aydin, 2013, p. 514).

Among the WPC panels, all the highest mechanical properties values were obtained for panels produced with high press temperature and pressing time. The usage of both high press temperature and high pressing time in the manufacturing of WPC panels caused an increase in mechanical properties. This may be explained due to having higher density values as seen from Table 2. Aydin (2004) stated that bonding strength increased with increasing density. Adhesive bonding strength is greatly affected by pressing time. Too short pressing time is insufficient as good adhesive penetration (Ahmad \& Osman, 2011, p. 6). In generally, it is well known from literatures resources that the mechanical properties and the bonding properties of plywood panel improve with increased of pressing time (Hoong \& Paridah, 2013, p. 145; Kurowska, Borysiuk \& Maminski, 2011, p. 495).

The previous study evaluates the possibilities of polystyrene wastes in plywood production as a bonding material. All mechanical properties of traditional plywood panels with urea formaldehyde adhesive were found to be higher than those of WPC panels. The usage of polystyrene as binder in the manufacturing of WPC panels caused a decrease in mechanical properties (Demirkir, Colak \& Aydin, 2013, p. 514). In this study, the bonding strength mean values obtained from the samples of WPC panels were above the limit value $\left(1.0 \mathrm{~N} / \mathrm{mm}^{2}\right)$ indicated in DIN 68705-3 (2003) standard. WPC panels produced using at 130 and 140 ${ }^{\circ} \mathrm{C}$ and 6 minutes did not provide DIN 68705-3 (2003). The bending strength and modulus of elasticity values of WPC panels were higher than 40 and $4000 \mathrm{~N} / \mathrm{mm}^{2}$ determined according to DIN 68705-3 (2003), respectively. Panels produced using at $1300^{\circ} \mathrm{C}$ and 6 minutes did not provide DIN 68705-3 (2003), but they exceeded 34.47 $\mathrm{N} / \mathrm{mm}^{2}$ determined according to the form 
was arranged by APA (2010) and showed the mechanical properties of structural plywood panels.

\section{Conclusion}

The aim of the study was to investigate those effects of press parameters on some technological properties of polystyrene wastes in plywood production as a bonding material. These parameters are different pressing time (6,8 and $10 \mathrm{~min}$.) and different pressing temperature $\left(130,140\right.$ and $\left.150{ }^{\circ} \mathrm{C}\right)$. From the experiment, it is found that the average mechanical properties tend to increase when the pressing time and temperature are increased during samples preparation. This study showed that polystyrene wastes can be used in plywood manufacturing as an alternative bonding material for interior uses.

\section{Acknowledgement}

This study was presented in International Forestry Symposium in University of Kastamonu, 2016. The authors acknowledge the financial support of this study by TUBITAK (The Scientific and Technical Research Council of Turkey) (Project No: 2140743).

\section{References}

Ahmad, M. \& Osman, S. (2011). Study on bonding strength of bamboo/bamboo unidirectional laminate with $U F$ and $P F$ effect of pressing time on adhesive bonding strength. 18th International Conference on Composite Materials (ICCM18); Korea: Jeju Island.

APA. (2010). The Engineered Wood Association. Technical Topics. Form No: TT-044B, March.

Aydin, I. (2004). Effects of some manufacturing conditions on wettability and bonding of veneers obtained from various wood species. $\mathrm{PhD}$ thesis, KTU Graduate School of Natural and Applied Sciences, 219 p., Trabzon.

Aydin, I. \& Colakoglu, G. (2008). Variations in bending strength and modulus of elasticity of spruce and alder plywood after steaming and high temperature drying. Mechanics of Advanced Materials and Structures, 15 (5), 371-374.
Bohm, M., Salem, M.Z.M. \& Srba, J. (2012). Formaldehyde emission monitoring from a variety of solid wood, plywood, blockboard and flooring products manufactured for building and furnishing materials. Journal of Hazardous Materials, 221-222, 68-79. doi: 10.1016/j.jhazmat.2012.04.013.

Colakoglu, G. (1993). Effect of the production parameter on formaldehyde emission and technical properties of plywood. $\mathrm{PhD}$ thesis, KTU Graduate School of Natural and Applied Sciences, 21 p., Trabzon.

Demirkir, C., Özsahin, S., Aydin, I. \& Colakoglu, G. (2013). Optimization of some panel manufacturing parameters for the best bonding strength of plywood. International Journal of Adhesion \& Adhesives, 46, 14-20.

Demirkir, C., Colak, S. \& Aydin, I. (2013). Some technological properties of woodstyrofoam composite panels. Composites part B-Engineering, vol.55, pp.513-517

DIN 68705-3, 2003. Structure Plywood. German Standards Institute, Verlag.

Fang, L., Chang, L., Guo, W., Ren, Y. \& Wang, Z. (2013). Preparation and characterization of wood-plastic plywood bonded with high density polyethylene film. European Journal of Wood and Wood Products, 71, 739-746.

Hoong, Y. B. \& Paridah, M. T. (2013). Development a new method for pilot scale production of high grade oil palm plywood: effect of hot-pressing time. Journal Material and Design, 45, 145.

Hu,Y., Nakao, T., Nakai, T., Gu, J. \& Wang, F. (2005). Vibrational Properties of Wood Plastic Plywood. Journal of Wood Science, 51, 13-17.

IARC. (2004). Overall evaluations on carcinogenicity to humans. In: As evaluated in IARC monographs, vol. 1. Lyon, France: International Agency for Research on Cancer.

Jianying, X., Tao, J., Yingyan, G., Min, Z. \& Xia, Z. (2010). Reduction of formaldehyde emission of wood-based panels. Bioinformatics and Biomedical Engineering (iCBBE), $2010 \quad 4$ th International Conference on (18-20 June), 1-3, Chengdu, Chine. 
Kurowska, A., Borysiuk, P., \& Maminski, M.L. (2011). Simultaneous veneers incising and lower pressing temperatures - the effect on the plywood pressing time. European Journal of Wood and Wood Products, 69, 495-7.

Luo, J., Luo, J., Gao, Q., \& Li, J. (2015). Effects of heat treatment on wet shear strength of plywood bonded with soybean meal-based adhesive. Industrial Crops and Products. 63, 281-285.

TS EN 310. (1999). Wood based panels. Determination of modulus of elasticity in bending and of bending strength. Turkish Standards Institute, Ankara.

TS EN 314-1. (1998). Plywood - Bonding quality - Part 1: Test methods. Turkish Standards Institute, Ankara.

TS EN 322, (1999). Wood-based panelsDetermination of moisture content. Turkish Standards Institute, Ankara.

TS EN 323-1. (1999). Wood- Based panelsDetermination of density. Turkish Standards Institute, Ankara. 